\title{
Symbiotic Induction of Pyruvate Dehydrogenase Genes from Sinorhizobium meliloti
}

\author{
Didier Cabanes, Pierre Boistard, and Jacques Batut \\ Laboratoire de Biologie Moléculaire des Relations Plantes-Microorganismes. CNRS-INRA BP27 31326 \\ Castanet-Tolosan Cedex, France \\ Accepted 19 January 2000.
}

\begin{abstract}
Genes coding for components of the pyruvate dehydrogenase (PDH) multienzyme complex (PDHc) from Sinorhizobium meliloti, the alfalfa symbiont, have been isolated on the basis of their high expression in symbiotic bacteria. The E1p component, PDH, is encoded by two genes, $p d h A \alpha(1,047$ bp) and $p d h A \beta(1,383$ bp), a situation encountered in the $\alpha$-proteobacteria Rickettsia prowazekii and Zymomonas mobilis as well as in some Gram-positive bacteria and in mitochondria. $p d h A \alpha$ and $p d h A \beta$ precede pdhB (1,344 bp), which encodes the E2p component, dihydrolipoamide acetyltransferase, of the PDHc. No gene encoding the $\mathrm{E} 3$ component, lipoamide dehydrogenase, was found in the immediate vicinity of $p d h A$ and $p d h B$ genes. $p d h A \alpha, p d h A \beta$, and $p d h B$ likely constitute an operon. Here, we provide evidence that $p d h A$ expression is induced in the symbiotic stage, compared with free-living conditions. We demonstrate that symbiotic expression of $p d h A$ genes does not depend on the fix $L J$ regulatory cascade that regulates nitrogen fixation and respiration gene expression in symbiotic $S$. meliloti cells. Induction of pdhA expression could be obtained under free-living conditions upon the addition of pyruvate to the culture medium. Induction by pyruvate and symbiotic activation of $p d h$ gene expression take place at the same promoter.
\end{abstract}

Sinorhizobium meliloti is an $\alpha$-proteobacterium that lives either as a free-living cell in the soil or as an intracellular symbiont plant of alfalfa and closely related legume species. The bacteria establish symbiosis by eliciting the formation of nodules on plant roots, in which they differentiate into bacteroids capable of fixing atmospheric nitrogen into ammonia to the benefit of the host plant (Mylona et al. 1995). Rhizobia are strict aerobes that make up the energy required for nitrogen fixation by operation of a tricarboxylic acid (TCA) cycle coupled to oxidative phosphorylation. To cope with the low ambient oxygen concentration of the nodule (10 to $30 \mathrm{nM} \mathrm{O}_{2}$ ), rhizobia synthesize a specialized oxidase complex with high affinity for oxygen (Preisig et al. 1993). Expression of the corresponding fixNOQP operon is itself under $\mathrm{O}_{2}$ control via a master two-component regulatory system, fixLJ, that also

Corresponding author: Jacques Batut; Telephone: 335612850 54; Fax: 335612850 61; E-mail: jbatut@toulouse.inra.fr

Nucleotide and/or amino acid sequence data can be found at the EMBL data base as accession no. AF190792. controls nitrogenase synthesis in $S$. meliloti (David et al. 1988). In contrast to free-living bacteria and to bacteria at the early stages of plant colonization, nitrogen-fixing $S$. meliloti cells heavily depend on dicarboxylic acids (succinate, malate, and fumarate) as carbon sources. These compounds are provided by the plant partner and are translocated to the bacteroid by the action of two permeases located in the peribacteroid membrane and in the bacteroid membrane (McRae et al. 1989). The bacterial enzyme is a high affinity permease encoded by a single gene, dctA, that is required for entry of dicarboxylic acids in bacteroids. Accordingly, an S. meliloti $d c t A$ mutant is strictly unable to perform symbiotic nitrogen fixation $\left(\mathrm{Fix}^{-}\right)$(Engelke et al. 1987).

Because succinate, fumarate, and malate are intermediates of the TCA cycle, operation of the cycle requires anaplerotic synthesis of acetyl-CoA. It was proposed that acetyl-CoA is mainly generated in bacteroids from the combined activities of malic enzymes and pyruvate dehydrogenase (PDH; Driscoll and Finan 1993). So, PDH was postulated to be a key enzyme of carbon metabolism in bacteroid. However, genes coding for the PDH complex (PDHc), which catalyzes the irreversible oxidative decarboxylation of pyruvate to acetyl-CoA, have not been identified so far in $S$. meliloti or in other rhizobia.

In the course of a screening for $S$. meliloti genes highly expressed under symbiotic conditions, we have isolated an expressed sequence tag (EST) whose sequence analysis suggested that it encodes subunit E1p of the PDHc. Here we report on the isolation, genetic organization, and regulation of the $S$. meliloti $p d h$ genes. Three genes have been found that encode the E1p and E2p components of the PDHc. Subunit E1 is encoded by two genes that are orthologues of genes found in other $\alpha$-proteobacteria, in some Gram-positive bacteria, and in mitochondria. We show a preferential $p d h A$ expression in the symbiotic stage, compared with free-living conditions, even when $\mathrm{C}_{4}$-dicarboxylates were used as sole carbon source. We provide evidence that $p d h A$ symbiotic expression is not regulated by oxygen and does not depend on the nitrogen status of the nodule. We have found that $p d h$ expression can be induced by pyruvate in free-living cultures.

\section{RESULTS}

PDH cDNA isolation from $S$. meliloti bacteroids.

The development of $\mathrm{N}_{2}$-fixing nodules requires the concerted expression of many bacterial and plant genes. On the bacterial side, most of the genes identified so far are involved 
in nitrogenase synthesis, the enzyme complex responsible for the reduction of $\mathrm{N}_{2}$ into ammonia, or in energy production. These genes are under the control of oxygen, as their expression can be induced ex planta under microoxic conditions (Soupène et al. 1995). To identify other symbiotically important genes, we looked for genes that are highly expressed in bacteroids, compared with free-living oxic and microoxic bacteria. The selected method was the RAP ( primed) PCR (polymerase chain reaction) fingerprinting technique (Welsh et al. 1992; Wong and McClelland 1994). This method can be used to detect and clone transcripts that are differentially expressed in cells subjected to different environmental conditions. Briefly, total RNAs are reverse transcribed from an arbitrary primer into a first strand of cDNA. The second cDNA strand is synthesized with a second arbitrary primer and amplified by PCR. Products separated on a sequencing gel are compared, and differentially expressed cDNAs can be cloned.

We have compared gene expression patterns obtained with RNAs isolated from $S$. meliloti in free-living oxic, microoxic, and symbiotic conditions. This approach allowed us to isolate several ESTs differentially expressed during symbiosis (D. Cabanes, P. Boistard, and J. Batut, manuscript in preparation).

The present paper focuses on the characterization of one of these ESTs, 221 bp in size, that was predominant under symbiotic, compared with free-living oxic and microoxic condi- tions, and whose sequence analysis revealed a similarity with the $p d h A$ gene family.

\section{Structure of $p d h$ genes from $S$. meliloti.}

The full-length $p d h A$ gene was isolated by screening a genomic library of $S$. meliloti (kindly provided by T. Arcondeguy), with the 221-bp EST as a probe. From a selected cosmid clone, $3.9 \mathrm{~kb}$ of nucleotide sequence was determined on both DNA strands around the original EST with a primerwalking approach; relevant portions are presented in Figure 1. Several open reading frames (ORFs) were predicted from this nucleotide sequence with both the GLIMMER program (Salzberg et al. 1998) and NCBI-BLASTX comparisons against the NCBI-nr data base. Three ORFs exhibited significant similarities with components of the PDHc. The PDHc catalyzes the oxidative decarboxylation of pyruvate, the transfer of an acetyl moiety to $\mathrm{CoA}$, and the reduction of $\mathrm{NAD}^{+}$ (pyruvate $+\mathrm{CoA}+\mathrm{NAD}^{+} \rightarrow$ acetyl-CoA $+\mathrm{NADH}+\mathrm{CO}_{2}$ ) by the combined action of three enzymes: PDH (E1p), dihydrolipoamide acetyltransferase (E2p), and lipoamide dehydrogenase (E3) (Patel and Roche 1990).

The predicted first and second ORFs were 1,047 and 1,383 bp in length, respectively. Translated sequences from these ORFs showed high similarity with the $\alpha$ and $\beta$ subunits of the heterotetrameric E1p component of known PDH complexes (Figs. 2-4). The first ORF, named $p d h A \alpha$, encodes a polypeptide of 348 amino acids, corresponding to a protein of $38 \mathrm{kDa}$,

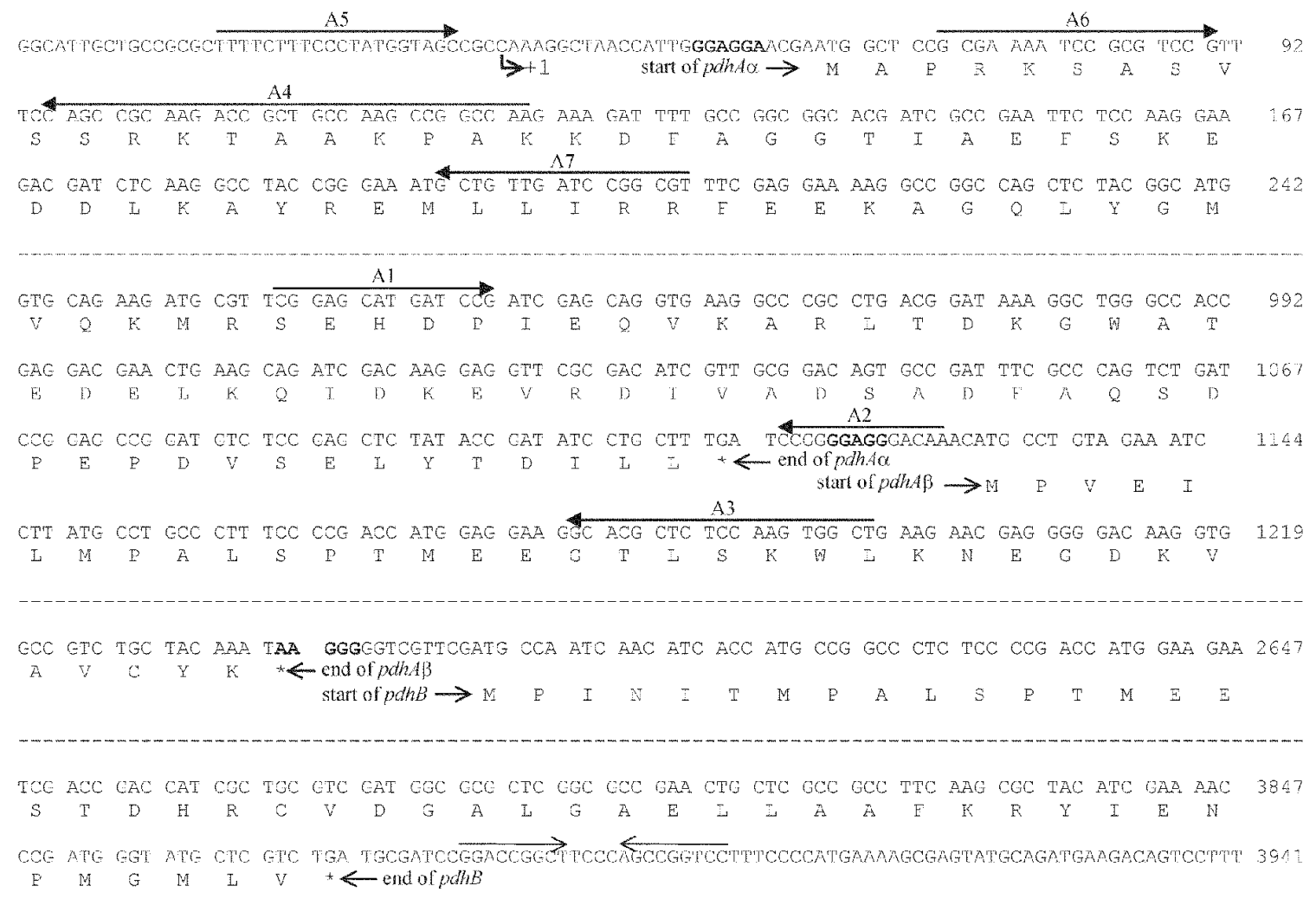

Fig. 1. Relevant portions of the nucleotide sequence of the Sinorhizobium meliloti pdhA $\alpha \beta$ and $p d h B$ genes. Deduced amino acid sequence is shown below nucleotide sequence. Putative ribosome-binding sites (RBS) are shown in bold. Transcriptional start site upstream of $p d h A \alpha$ is marked with an arrow. Putative $\rho$-independent transcriptional terminator is shown. Primers used for polymerase chain reaction, reverse transcription-polymerase chain reaction, and primer extension reactions are indicated. Accession number of the sequence is AF190792. 
with highest sequence identity to the E1 $\alpha$ subunit of the PDHc of two other $\alpha$-proteobacteria, Zymomonas mobilis (59\% identity) and Rickettsia prowazekii (52\% identity), and eukaryotic mitochondria (Homo sapiens, $51 \%$ identity; Arabidopsis thaliana, $48 \%$ identity). The $S$. meliloti $\mathrm{E} 1 \alpha$ predicted polypeptide contains the thiamine pyrophosphate (TTP)-binding site (residues 172 to 202) involved in binding metal ion, and conserved in TTP-binding enzymes (Hawkins et al. 1989) (Fig. 2).

The start of the second ORF, named $p d h A \beta$, was assigned 18 bp downstream of the $p d h A \alpha$ gene. $p d h A \beta$ encodes a polypeptide of 460 amino acids, corresponding to a protein of $49 \mathrm{kDa}$ with highest sequence identity $(58 \%)$ to the $\mathrm{E} 1 \beta$

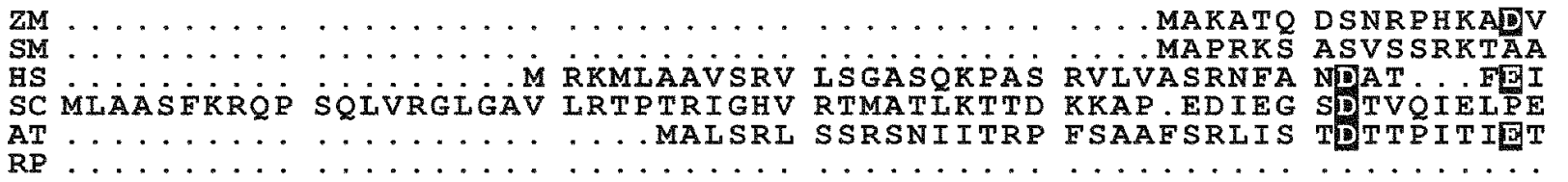

\section{6}

16 38 59 36

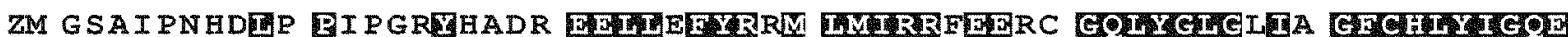
SM KPAKKDEAGG TIA. B FISR DDDLRAYRDL HS KKCDIHRLEV GPPVTTVLTR EDGLKT IRMM SC S. SFESYMUE PEDLSYETSK ATILQMTKDU AT SLPFTAHLCD PESRSVESSS OFTLDFETM

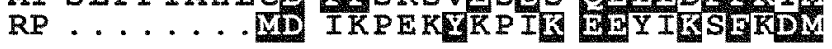
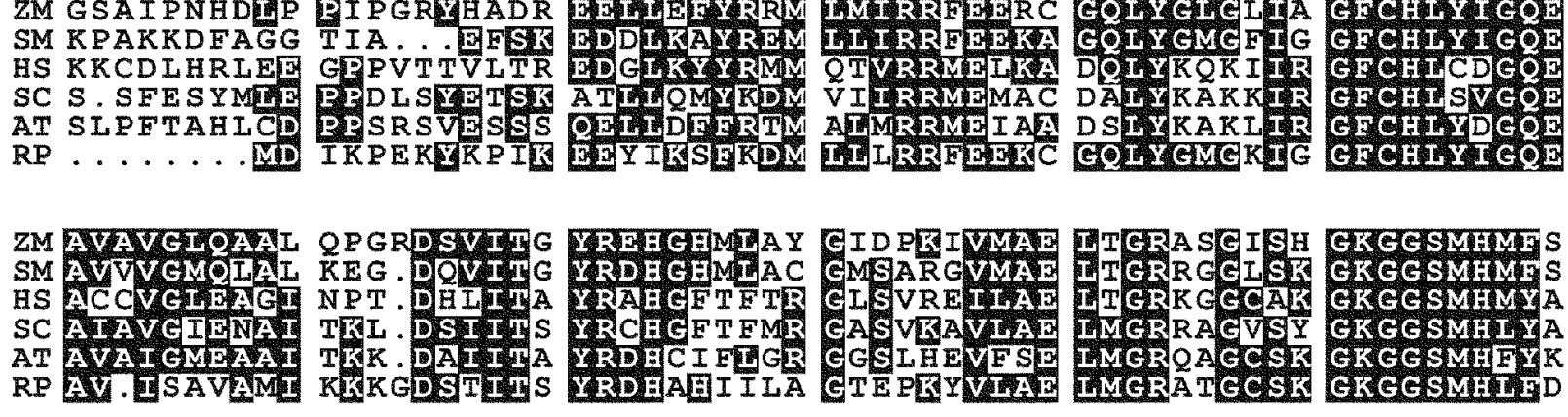

GKGGSNHMES 136 CKGGSMHM 132 GR GG SMHMY A 157 GKGGSMH I YA 177

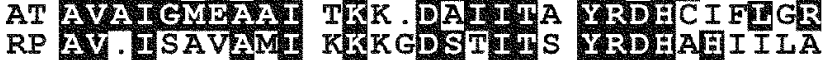

TTP-binding domain

ZM TVH KFमCCNe SM R R K K T GEHG HS K. NEYGGNG AT RT S SBY ECHE RP IPNKEYGGHC
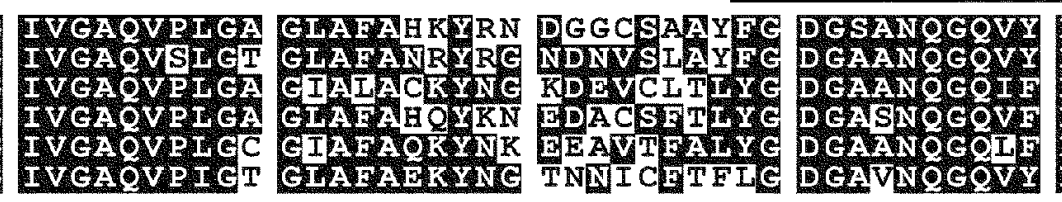

\begin{tabular}{|c|c|}
\hline 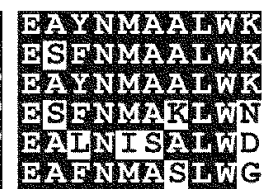 & \\
\hline
\end{tabular}
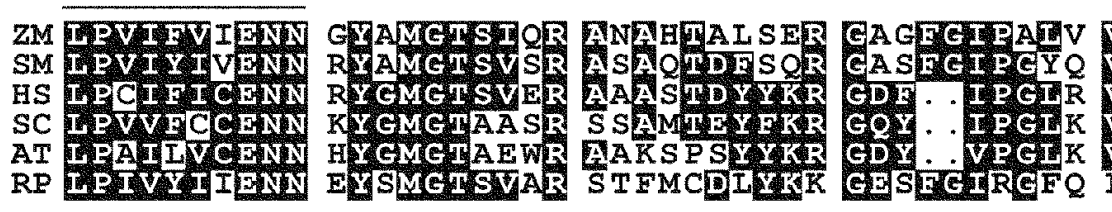

VDCMDVI
VD GMDYRA

R GAATVAVDWV 256

SM IT PV I Y I VENN

AT TPATLVCEN

RP LPIVYIIEND

AAKSPSTYKR

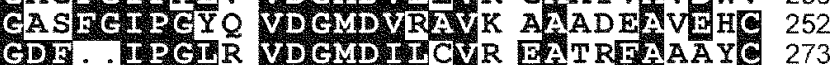

GQ1. IPGTK VNGMD I TAYY QASK FAKDWC 293

ZM QAGKGPI T T

SM RSGK GP I I I
HS R GKCP I IM

SC IISCKGPLVL

AT IE . KEP I I 5

RP BENSERVIL
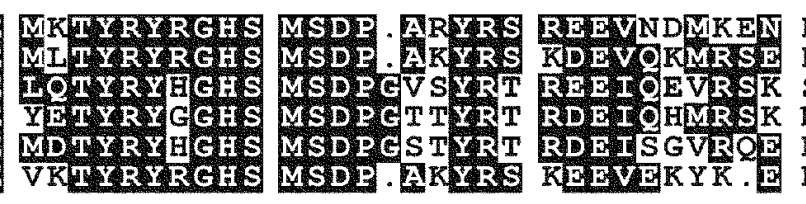

ID EUD FEEMY

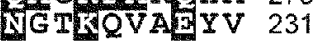
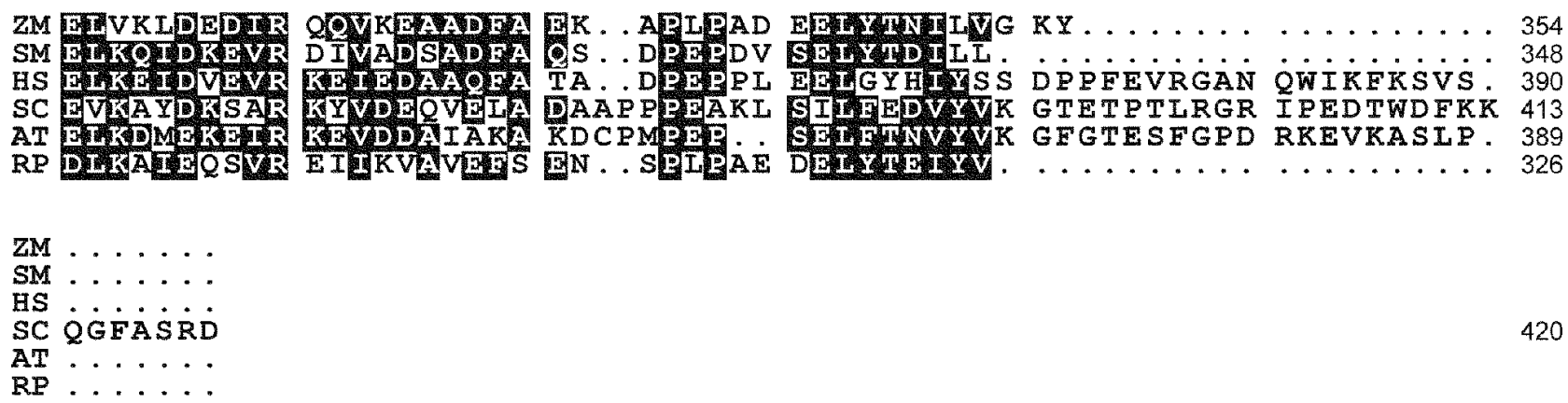

420

Fig. 2. Alignment of amino acid sequences of the $\mathrm{E} 1 \alpha$ components of pyruvate dehydrogenase (PDH) complexes from Arabidopsis thaliana (AT), Homo sapiens (HS), Rickettsia prowazekii (RP), Saccharomyces cerevisiae (SC), Sinorhizobium meliloti (SM), and Zymomonas mobilis (ZM). Amino acids conserved in at least three out of the six sequences are shaded. Functional domains identified in homologous proteins are indicated above the amino acid sequences. EMBL accession numbers of sequences used: AT, AAD39331; HS, CAA36933; RP, CAA14723; SC, CAA50657; ZM, CAA73384. 
subunit of the Z. mobilis PDHc (Fig. 3). Like its Z. mobilis homologue, the $S$. meliloti $\mathrm{E} 1 \beta$ component contains an extension at the $\mathrm{N}$ terminus (residues 2 to 77 ), identified as a lipoyl domain. This lipoyl domain contains a highly conserved ly- sine residue ( $\mathrm{K} 43)$ that is the potential lipoylation site, and the P(S/A)LSPTM (residues 8 to 14) sequence motif (Fig. 3).

The third predicted ORF (1,344 bp) started $13 \mathrm{bp}$ after $p d h A \beta$. The $S$. meliloti $p d h B$ gene encodes a protein of 447

Lipoyl domain

ZM MAIEIKM SM MPVEILMPAI SPTMEEGTLS KWLKNEGDKV SSGDVIAEIE TDEATMEVEA VDKGTIGKIL

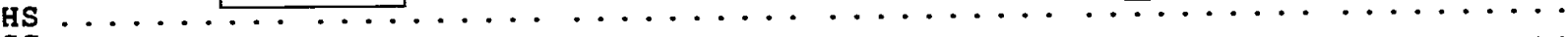

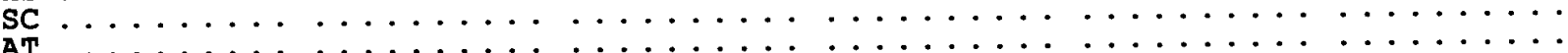

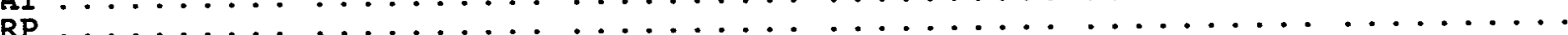

ZM IPEGSENVKV GTAIAYLGTD ANDVTLEGAS AETKAEESAP VASPAKTEAA ALEEAATPSI SM IAAGTEGVKV NTPIAVLLOD G. EAASDIDS MKTEAPK.AE TPKPAAAEAP AASAAPVAAO SM IAAGTEGVKV NTPIAVILQD G. EAASDIDS MKTEARK. AE TPKPAAA MAA VSGIVRRPLR

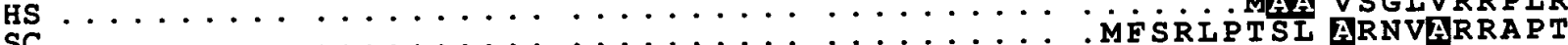

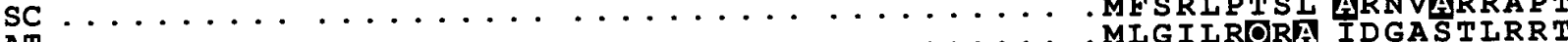
AT $\ldots \ldots \ldots \ldots . \ldots \ldots$ MLGILRORA IDGASTLRRT

ZM GKV. INSAPE IPEGTEEFQO SM PKADVPSDPA IPAGTEMATM HS EVSGLIKRRF HWTAPAALQV SC SFVRPSAAAA ALRESSTRTM AT REALVSARSY A. . A A KA KMM
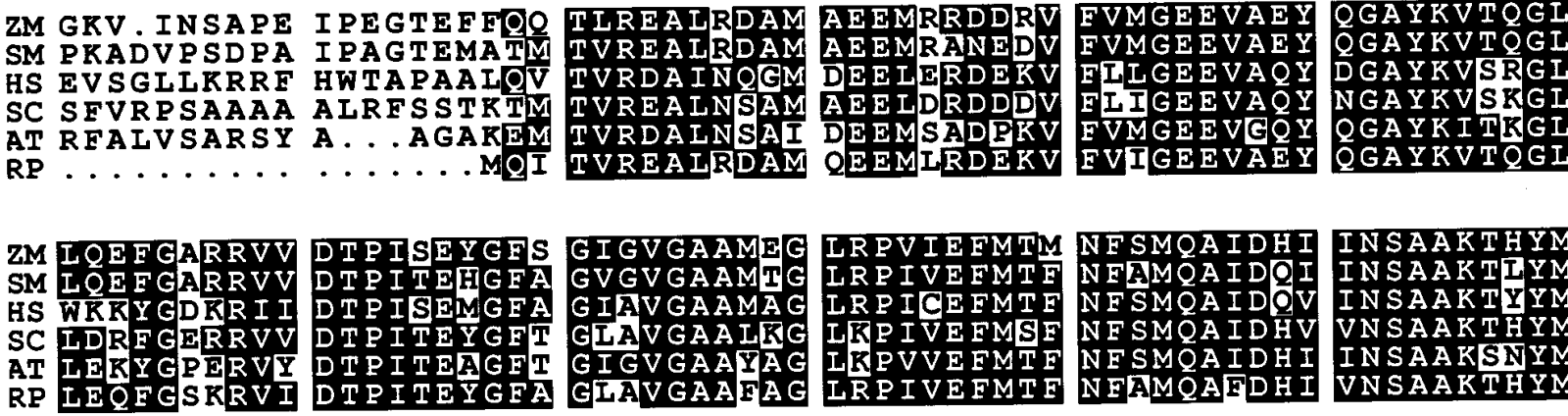

239

238

133

139

136

103
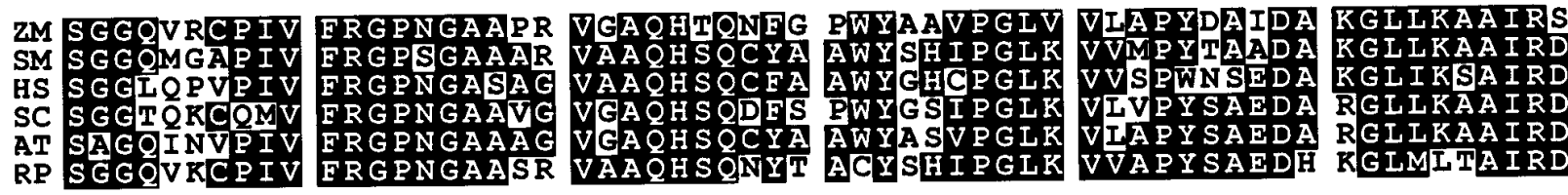

299
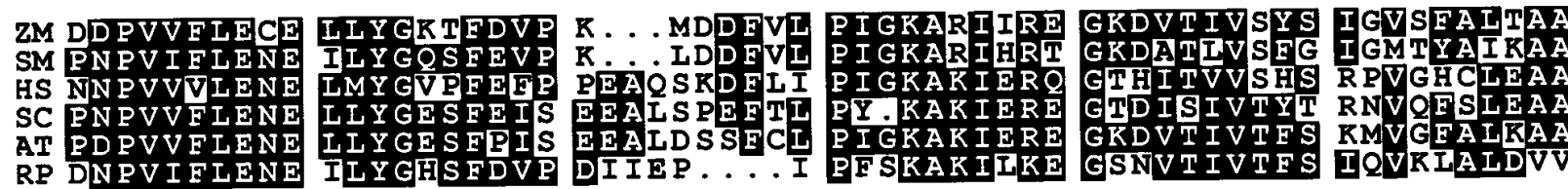

356
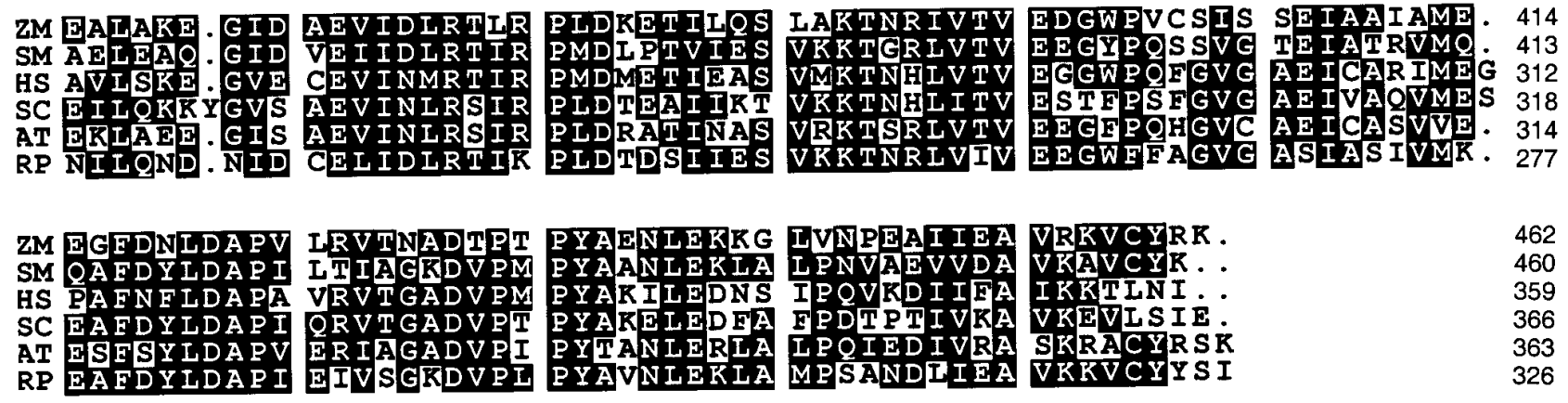
conserved in at least three out of the six sequences are shaded. Functional domains identified in homologous proteins are indicated above the amino acid sequences. The P(A/S)LSPTM motif and the lipoylation site are boxed. EMBL accession numbers of sequences used: AT, AAA52225; HS, CAA40924; RP, CAA14724; SC, CAA85184; ZM, CAA73385. 
amino acids with a predicted molecular mass of $46 \mathrm{kDa}$ that exhibited significant sequence similarity with the dihydrolipoamide acetyltransferase (E2p) component of the PDHc from many different species (Fig. 4). S. meliloti E2p shows high identity to the sequence of E2p components of Z. mobilis (42\%), R. prowazekii (42\%), and mitochondrial dihydrolipoamide acetyltransferases (A. thaliana, 41\%; Saccharomyces cerevisiae, $38 \%)$. S. meliloti E2p has the characteristic

Lipoyl domain

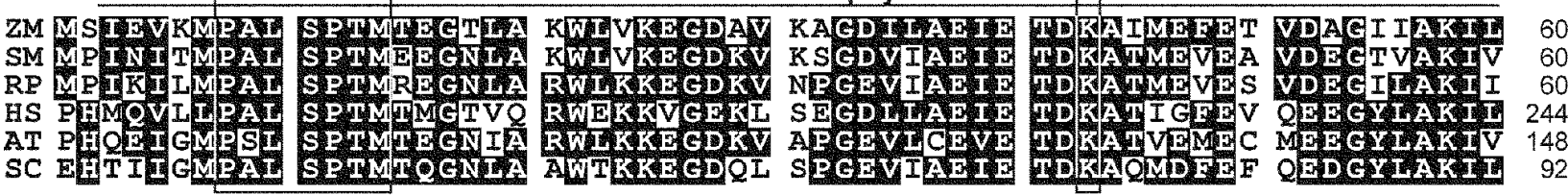

ZM VPECSENTAV GQVTAVMAEA GHDVSQVAAS AS SOISERSE KADVAQKETA DSETTSIDAS 120 SM VPACTEGVKV NALI AVIAAV GLDVATAAKG GNGAAGAVPA PKP... KUTA DTAPAAAPAP 117 RP IPQNSONVPV NSIIAVISET EDDKADIDST .

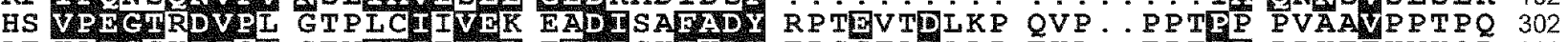
AT KADCSKDIOV GEVTATTVDD EEDIGKEKDY TPSSTADAAP TKA. . EPTPA PPKEEKVKQP 206 SC VPDCUKDIRV NKPIAVYVED KADVPAEKDE KLEDSGSDSK TST. RAQPA EPQAEKKQEA 150

Subunit binding domain

ZM LDKAISNAGY GNKTENMTAS YQEKAGRIKA SPIAKRIAAK NHDDIKOVSE SEPECRI IKA 180 SM AAABAEQAA. ...APASEAP ADGEGKRTES SPLARRIAKT ACIDISAIAC SCPECRVVKK 173 RP TDATIKKS... NDSITNVEG IKHDSNKTFA SPIAKRIAKI GDIRIENVQC SGPHCRTVKQ 159 HS PIAPTESAP. ...... CPAT PAGPKGRVEV SPIAKIIAVE KGIDITOVKE TGPDCRITKK 355 AT SSPEETKAS. .....KRST PP.TGDRVFA SPIARKLAED NNVPTSDTEC TEPECRTVRA 258 SC PAEETKTSA. . . PEAKKSD VAAPQGRIFA SPLAKTIAID KGISIKDVHC TGDRGRITKA 206

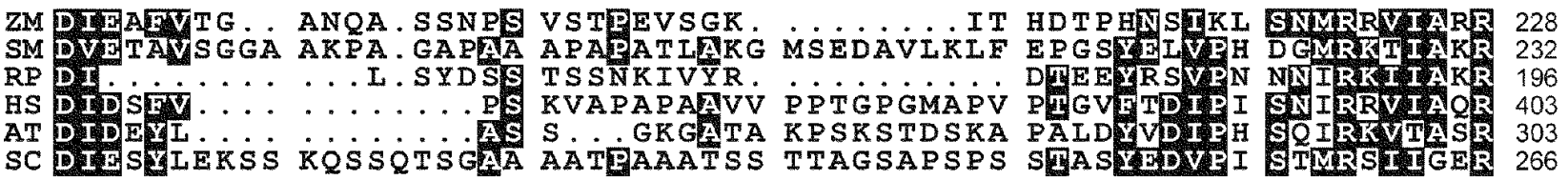

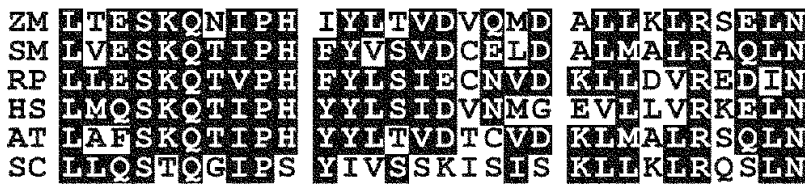

ESLAVON . . IETSVIDMIL IRAOALALKA 284 AAAPEKDGKP VYKLSVNDMV IKALATALRD 292 KSFSEDK... VTKISVNDFI IIAVAKALQE 253 KILO. . GR . SKTSVNDFI ITASAITCIK 458 SFKDASGG... KRISVNDIV VRAAALAIRK 360 ATAN. DKK . YKISINDIL VKAITVAARR 321

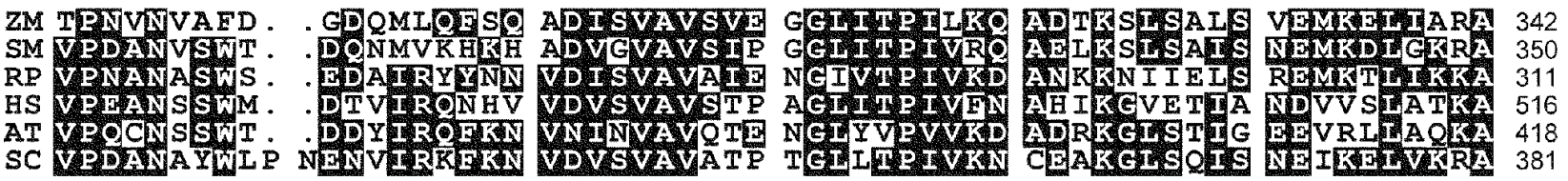

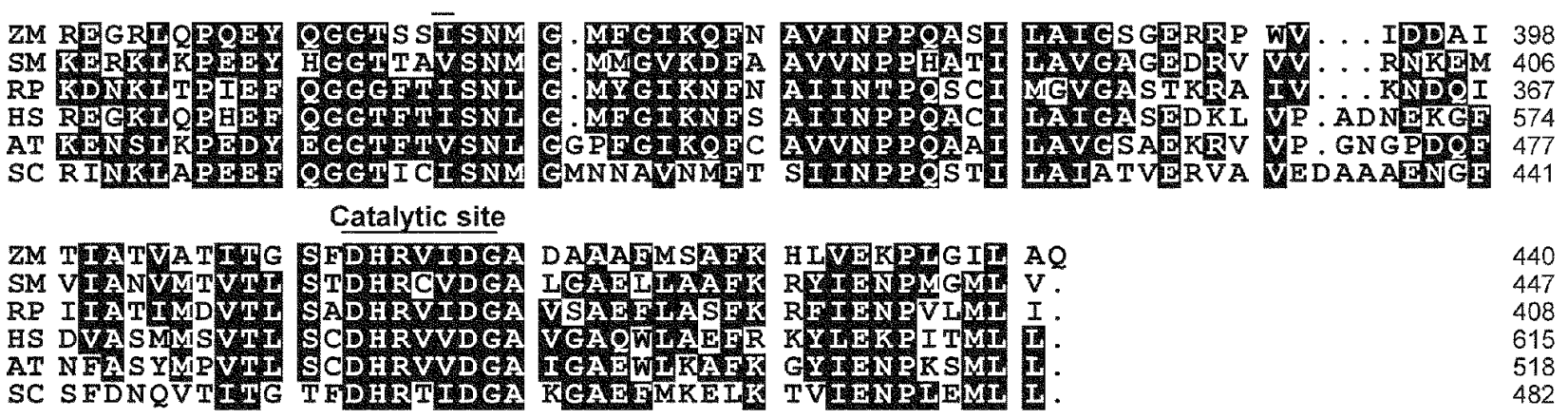

Fig. 4. Alignment of amino acid sequences of the E2p components of pyruvate dehydrogenase (PDH) complexes from Arabidopsis thaliana (AT), Homo sapiens (HS), Rickettsia prowazekii (RP), Saccharomyces cerevisiae (SC), Sinorhizobium meliloti (SM), and Zymomonas mobilis (ZM). Amino acids conserved in at least three out of the six sequences are shaded. Functional domains identified in homologous proteins are indicated above the amino acid sequences. The P(A/S)LSPTM motif and the lipoylation site are boxed. EMBL accession numbers of sequences used: AT, AAD25602; HS, CAA68787; RP, CAA14979; SC, CAA60189; ZM, CAA63808. 
multidomain structure of E2 components in which the aminoterminal lipoyl domain, the subunit-binding domain, and the C-terminal catalytic domain are separated by flexible linkers (Fig. 4). The carboxy-terminal domain contains the active-site motif $\mathrm{S}-\mathrm{X}_{51}-\mathrm{H}-\mathrm{X}_{3}$-DG common to all E2 enzymes (Russell and Guest 1991). The $S$. meliloti E2p component possesses a single lipoyl domain, like Z. mobilis E2p, with the characteristic P(S/A)LSPTM motif (residues 8 to 14 ), and lipoylation site (K 43).

An ORF was detected 137 bp upstream of $p d h A$, with sequence similarity $(52 \%)$ to $R$. prowazekii ORF-782 of unknown function that, in this organism, is unlinked to $p d h$ genes (Andersson et al. 1998). Numerous $p d h$ operons have a lpd lipoamide dehydrogenase (E3) gene immediately downstream of E1p and E2p. However, no lpd gene was found in $S$. meliloti, immediately downstream of $p d h B$. Instead, an ORF starting 51 bp downstream of $p d h B$ displayed sequence similarity to an arylesterase from Agrobacterium radiobacter (AAD02335).

The small distances separating $p d h A \alpha, p d h A \beta$, and $p d h B$ (17 bp between $p d h A \alpha$ and $p d h A \beta$, and 12 bp between $p d h A \beta$ and $p d h B$ ) suggest that these three genes might be cotranscribed. Direct evidence for co-transcription of the two $p d h A$ genes was indeed obtained by reverse transcription (RT)-PCR analysis with two specific primers (A3 and A1; see Figure 1), and RNAs extracted from symbiotic bacteroids. This experiment demonstrated the existence of a $p d h A \alpha$ $p d h A \beta$ co-transcript (data not shown). Downstream of $p d h B$, an inverted repeat followed by several $U$ residues was identified (Fig. 1), and could act as a transcriptional termination signal.

As the $S$. meliloti genome contains many repeated genes (Fischer 1994), the number of $S$. meliloti E1p gene copies was determined by Southern blot analysis. Genomic DNA was isolated, digested with BamHI, EcoRI, HindIII, SalI, or SmaI, and hybridized with a $p d h A$-specific (A1-A2) probe. The presence of a single hybridization band in all cases was consistent

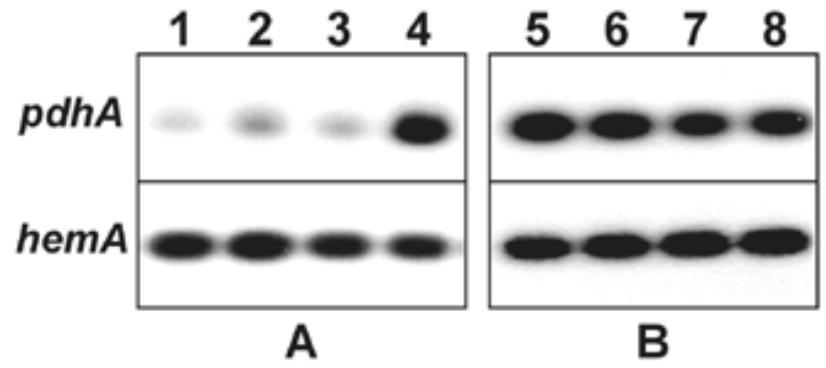

Fig. 5. $p d h A$ expression is induced under symbiotic conditions independently of fixLJ regulatory pathway. A, Autoradiographs of reverse transcription-polymerase chain reactions (RT-PCRs) of RNAs isolated from (lane 1) free-living oxic, (lane 2) microoxic $\left(2 \% \mathrm{O}_{2}\right)$, and (lane 3) stoppered tube assay (STA) $\left(<1 \% \mathrm{O}_{2}\right)$ Sinorhizobium meliloti bacteria grown in rich TY (tryptone-yeast) medium, and (lane 4) from symbiotic bacteroids 3 weeks after inoculation of alfalfa. pdhA: RT-PCR was performed with $p d h A$-specific primers (A1 and A2), and products hybridized with the $p d h A$ (A1-A2) ${ }^{32} \mathrm{P}$-labeled probe. hemA: RT-PCR was performed with specific primers of the constitutively expressed hemA gene to ensure that an equal amount of RNA was used in all reactions. B, Autoradiographs of RT-PCRs of RNAs isolated from symbiotic bacteroids 2 weeks after alfalfa inoculation with (lane 5) wild-type GMI 211, (lane 6) fixK GMI 942, (lane 7) nifA GMI 5601, and (lane 8) fixJ GMI 5704 S. meliloti strains. with E1p being encoded by unique genes in S. meliloti 8011 (data not shown).

\section{$p d h A \alpha \beta$ expression is induced in bacteroids, independently of the nitrogen fixation and respiration regulatory pathways.}

Originally, $p d h A \alpha \beta$ genes were isolated in the course of screening for $S$. meliloti genes highly expressed under symbiotic conditions, compared with free-living conditions. To confirm that $p d h A \alpha \beta$ expression was induced during symbiosis, RT-PCRs were performed on S. meliloti 211 total RNA, isolated from free-living oxic bacteria, free-living microoxic bacteria, and bacteroid 3 weeks after alfalfa inoculation by $S$. meliloti (see Materials and Methods). With specific primers synthesized from the $p d h A$ sequence (A1 and A2; see Figure 1), RT-PCR products were subjected to Southern hybridization with the 191-bp A1-A2 product generated by PCR on $S$. meliloti total DNA. Data showed that $p d h A$ gene transcripts accumulated at a high level in symbiotic conditions, compared with free-living conditions (Fig. 5A). To control the amount of RNA in the reaction, the constitutively expressed $S$. meliloti hemA gene (Batut et al. 1989) was in the same way subjected to the RT-PCR procedure with hemA specific primers (see Materials and Methods). No RT-PCR product was detected in controls lacking reverse transcriptase during cDNA synthesis, relative to background DNA contaminating the RNA preparations.

In S. meliloti, two master regulatory genes, nifA and fixK, control the expression of genes involved in nitrogen fixation and bacteroid respiration. These regulators are themselves under the control of the FixLJ two-component system that mediates oxygen signaling (David et al. 1988; Soupène et al. 1995). To test whether $p d h A$ symbiotic induction was under this pathway control, RT-PCRs were performed on RNAs isolated from different nif and fix S. meliloti mutant strains. RNAs were extracted from bacteroids 2 weeks after alfalfa inoculation with wild-type (GMI 211), fixK (GMI 942), nifA (GMI 5601), and fixJ (GMI 5704) S. meliloti strains. No effect of the different mutations on $p d h A$ symbiotic activation was detected (Fig. 5B). Similar data were obtained with a different set of primers (A1 and A3, Fig. 1; and data not shown).

\section{Pyruvate induces $p d h A$ expression in free-living cultures of S. meliloti.}

To test the effect of various carbon sources on $p d h A$ expression, RT-PCRs were performed on S. meliloti RNAs isolated from oxic or microoxic free-living cells grown in minimal medium containing different carbon sources $(20 \mathrm{mM}$; see Materials and Methods). Cells grown in M9 minimal media with either mannitol or succinate as sole carbon source showed a low level of $p d h A$ expression (Fig. 6A), much like cells grown in TY rich medium (Fig. 5A). No induction was observed in minimal medium supplemented with acetate (data not shown). By contrast, a large increase of the $p d h A$ RNA level was observed when pyruvate was the sole carbon source (data not shown), or when pyruvate was added to minimal media containing mannitol or succinate (Fig. 6A). Thus, pyruvate was capable of inducing $p d h A$ expression under freeliving conditions. Similar results were obtained when the cells were grown under oxic or microoxic-STA conditions (data not shown). 
The kinetics of induction by pyruvate were investigated by measuring $p d h A$ RNA levels at different times following pyruvate addition. RNAs were extracted from free-living cells 0 , $5,15,30$, and $60 \mathrm{~min}$ after addition of pyruvate to minimal medium containing succinate as carbon source. As shown in Figure $6 \mathrm{~B}$, induction of $p d h A$ expression was already detectable $5 \mathrm{~min}$ after pyruvate addition. After $15 \mathrm{~min}, p d h A$ transcripts leveled off. Hence, induction of $p d h A$ expression by pyruvate is fast.

Levels of $p d h A$ RNA reached in symbiosis or in free-living conditions upon addition of pyruvate were compared by RTPCR. Experiments were performed on total RNAs extracted from free-living bacteria grown in M9 minimal medium supplemented with succinate or with succinate and pyruvate, and from bacteroids. High levels of $p d h A$ transcripts were detected under the latter two conditions. However, $p d h A$ RNA levels from bacteroids were consistently higher (Fig. 6C). Thus, induction by pyruvate in free-living conditions was only partial, compared with $p d h A$ symbiotic activation.

\section{Pyruvate induction and symbiotic activation take place at the same promoter.}

The transcription start site of $p d h A$ was mapped by primer extension analysis with RNAs isolated from free-living cells grown in minimal medium supplemented with succinate and pyruvate and from 3-week-old symbiotic bacteroids. For primer extension, a primer complementary to the $5^{\prime}$ end of $p d h A \alpha$ coding region was used (A4; see Figure 1). The same elongation product was detected with RNAs from free-living bacteria induced by pyruvate and from symbiotic bacteroids. Transcription was shown to start $26 \mathrm{bp}$ upstream of the putative start codon of $p d h A$ (Figs. 7 and 1). The amount of the primer extension product generated was greater with RNAs isolated from bacteroids than with RNAs isolated from freeliving cells (Fig. 7). This is consistent with the $p d h A \alpha$ gene being more highly expressed in bacteroids than in free-living cultures (Fig. 6C). Existence of an additional transcription start site upstream or downstream of the one identified above was tested by RT-PCR experiments. RNAs were subjected to RT-PCR with different primer sets. With primers (A5 and A7; Fig. 1) surrounding the identified start site no product was detected, and with primers (A6 and A7; Fig. 1) downstream of the A4 primer no change was observed on the product levels (data not shown).
Altogether, these results indicate that pyruvate induction and symbiotic activation of $p d h A$ take place at the same promoter.

\section{DISCUSSION}

Structure and genetic organization of $S$. meliloti pdh genes.

We have cloned three $S$. meliloti genes whose predicted protein products display high sequence identity with components of the PDHc from several organisms, including the $\alpha$ proteobacteria Z. mobilis and $R$. prowazekii. The S. meliloti components identified have highest identity with subunits of $Z$. mobilis, from which the PDHc has been purified and biochemically characterized as such (Neveling et al. 1998b). Thus, the $S$. meliloti genes that we have isolated are likely orthologues of the $p d h A \alpha, p d h A \beta$, and $p d h B$ genes of $Z$. mobilis.

$p d h A \alpha$ and $p d h A \beta$ code for the $S$. meliloti E1p component, suggesting a heterotetrameric $E 1 \alpha_{2} \beta_{2}$ form, as described in the Gram-negative bacteria Z. mobilis (Neveling et al. 1998b) and

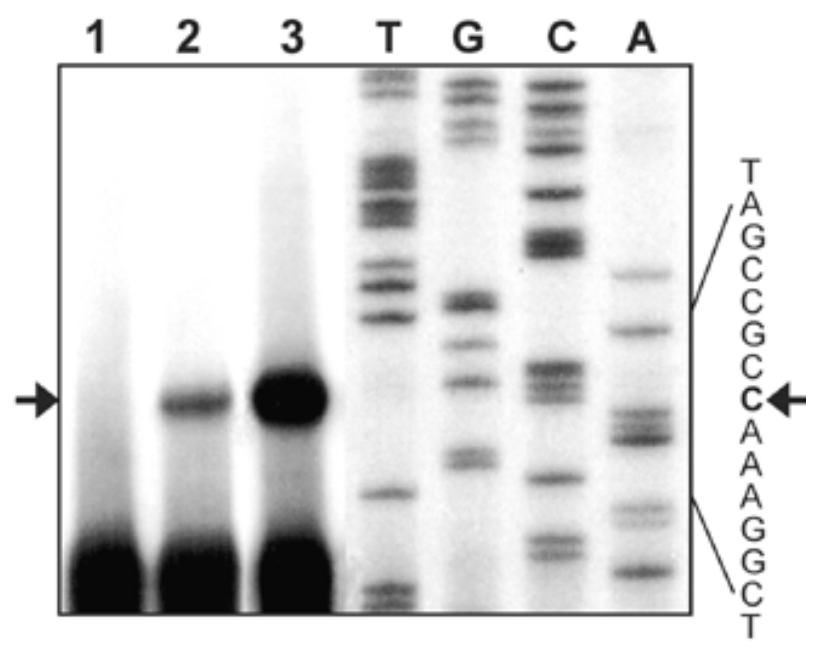

Fig. 7. Mapping of the $p d h A$ transcription start site. Primer extension analysis with RNAs isolated from free-living Sinorhizobium meliloti bacteria grown in minimal medium with succinate (lane 1) before and (lane 2) $4 \mathrm{~h}$ after pyruvate addition, and (lane 3 ) from symbiotic bacteroids 3 weeks after alfalfa inoculation with $S$. meliloti. Products of extension reactions were fractionated alongside a sequence ladder generated with the A4 primer used for primer extension.

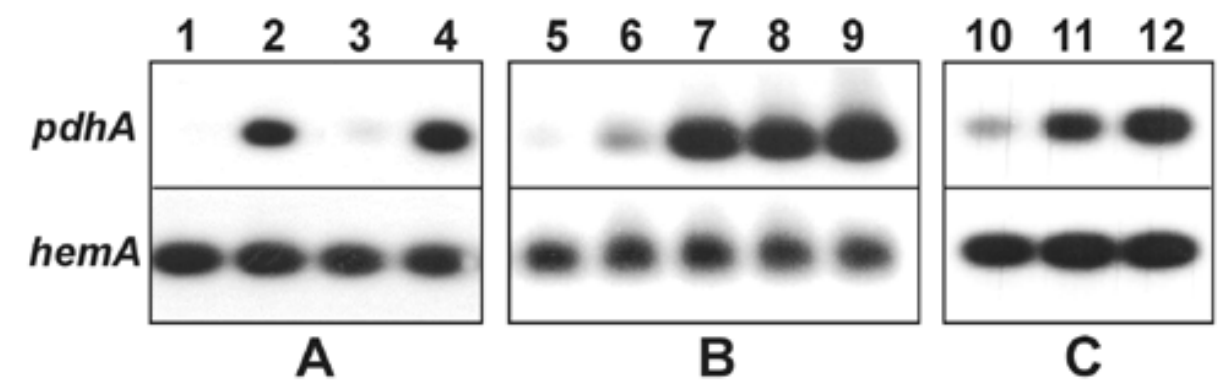

Fig. 6. Pyruvate activates $p d h A$ expression. A, Reverse transcription-polymerase chain reaction (RT-PCR) products were derived from RNA isolated from free-living oxic bacteria grown in minimal medium with (lane 1) mannitol, (lane 2) mannitol and pyruvate, (lane 3) succinate, or (lane 4) succinate and pyruvate as carbon sources. RNAs were extracted $4 \mathrm{~h}$ after addition of pyruvate. Similar results were obtained after $16 \mathrm{~h}$ (data not shown). B, Kinetics of $p d h A$ induction by pyruvate. RT-PCRs were performed on RNAs extracted from free-living oxic bacteria grown in minimal medium supplemented with succinate at different times $(0,5,15,30,60 \mathrm{~min}$ ) after pyruvate addition (lanes 5, 6, 7, 8, 9, respectively). C, pdhA expression analysis by RT-PCR on RNAs from free-living oxic bacteria grown in minimal medium with (lane 10) succinate, (lane 11) succinate plus pyruvate, or (lane 12) from symbiotic bacteroids 3 weeks after alfalfa inoculation with Sinorhizobium meliloti. 
Thiobacillus ferrooxidans (Powles and Rawlings 1997), and also in some Gram-positive bacteria and in mitochondria. The $S$. meliloti E1 $\alpha$ component contains the conserved TTPbinding site found in E1-type enzymes. Interestingly, the E1 $\beta$ subunit contains an amino terminus E1 $\beta$ lipoyl domain, like $Z$. mobilis $\mathrm{E} 1 \beta$ but unlike $R$. prowazekii $\mathrm{E} 1 \beta$. N-terminal lipoyl domains are usually found in E2p components, in which a covalently bound lipoyl group is essential for the coupling of the activities of the separate multienzyme components (Berg and de Kok 1997). Lipoyl domains are also found in the E3 component of multienzyme complexes from several species, but their role, as well as the role of the N-terminal lipoyl domain from $Z$. mobilis E1 $\beta$, has not yet been established.

The $p d h B$ gene encodes the E2p component of the complex. As in all other E2p, S. meliloti E2p has a multidomain structure, with an amino-terminal lipoyl domain, a subunit-binding domain, and a carboxy terminal catalytic domain separated by flexible linkers. In PDHc, the number of E2p lipoyl domains varies from one to three, and the reason for this variation is unknown. In complexes from Gram-negative organisms, the number is usually two to three, but $S$. meliloti possesses only one E2p lipoyl domain.

Comparison of amino acid sequences shows that PDHc enzymes from the three $\alpha$-proteobacteria $S$. meliloti, Z. mobilis, and $R$. prowazekii are evolutionarily clustered. Their E1p component is composed of two subunits, $\alpha$ and $\beta$, like the components of PDH complexes of some Gram-positive organisms and of mitochondria. These E1p components do not show homology to the E1p type found in Escherichia coli (CAA24740), Alcaligenes eutrophus (Q59097), Mycobacterium tuberculosis (CAA9466), or Streptomyces coelicolor (CAB51267). While E2p sequence analysis shows homology with the E2p proteins from eukaryotes and Gram-positive and Gram-negative bacteria, the three $\alpha$-proteobacteria E2p showed highest sequence identity to the sequences of eukaryotic E2p (Neveling et al. 1998a). Moreover, N-terminal lipoyl domains attached to the three $\alpha$-proteobacteria E2p and to the $S$. meliloti and $Z$. mobilis E1 $\beta$ components display the $\mathrm{P}(\mathrm{S} / \mathrm{A}) \mathrm{LSPTM}$ motif highly conserved in eukaryotic E2p lipoyl domain but absent in the E2p lipoyl domain of prokaryotes. Hence, PDHc enzymes from $\alpha$-proteobacteria show overall higher sequence identity with mitochondrial PDHc than with other Gram-negative PDHc components.

In the $S$. meliloti genome, $p d h A \alpha \beta$ and $p d h B$ are clustered as they are in other prokaryotic genomes, with the notable exception of $Z$. mobilis and $R$. prowazekii. We have shown the existence of a $p d h A \alpha-p d h A \beta$ co-transcript and the presence of a very short gap (12 bp) between the end of $p d h A \beta$ and the beginning of $p d h B$. In addition, a potentially stable stem-loop structure that could function as a $\rho$-independent transcriptional terminator was detected immediately downstream of $p d h B$ (Fig. 1). Altogether, these results suggest that the three $p d h$ genes form a transcriptional unit in S. meliloti, with a transcription start site 26 bp upstream of the proposed pdhA transcriptional start codon.

Southern analysis of genomic DNA showed that a single gene very likely encodes E1p in the $S$. meliloti genome, in contrast to Alcaligenes eutrophus, that possesses two paralogous genes coding for PDH (Hein and Steinbuchel 1996).

In prokaryotes, the E3 component is shared by different enzymatic complexes, such as 2-oxoglutarate dehydrogenase complexes (OGDHc) or acetoin dehydrogenase complexes $(\mathrm{ADHc})$, in addition to PDHc. Accordingly, the corresponding lpd gene can be part of different gene clusters (de Kok et al. 1998). In some prokaryotes, such as Bacillus subtilis and Staphylococcus aureus, an lpd gene lies immediately downstream of $p d h B$ (Neveling et al. 1998a). Instead, in S. meliloti, no lpd gene was found immediately downstream of $p d h B$, as described in A. vinelandii (Hengeveld et al. 1997) and $P$. aeruginosa (Rae et al. 1997).

\section{Symbiotic role of $p d h A$ induction.}

$\mathrm{C}_{4}$-dicarboxylic acids are the principal source of carbon supplied by the plant to $\mathrm{N}_{2}$-fixing bacteroids within the root nodules (Ronson et al. 1981). The use of $\mathrm{C}_{4}$-dicarboxylates as sole carbon source is dependent on the availability of acetylCoA. Bacteroids from alfalfa nodules lack phosphoenolpyruvate carboxykinase (PCK) activity (Finan et al. 1991). Thus, the pathway for formation of acetyl-CoA via oxaloacetate to phosphoenolpyruvate probably cannot operate in bacteroids. It was thus proposed that acetyl-CoA, which is essential for the TCA cycle operation, is generated via the combined activities of malic enzymes and PDH in bacteroids (Driscoll and Finan 1993). Accordingly, both malic enzymes and PDH activities have been detected in S. meliloti bacteroids (Driscoll and Finan 1993; Miller et al. 1991). In further support of this model, $S$. meliloti dme malic enzyme mutants induced root nodules that contained bacteroids that failed to fix nitrogen. We note that both dme expression and DME activity that generate pyruvate are not increased during symbiosis. $S$. meliloti has a second malic enzyme, TME, whose synthesis is repressed in bacteroids (Driscoll and Finan 1997). In this context, construction of a $p d h$ mutant and assessment of its symbiotic phenotype will be interesting. Given the central role of acetylCoA in the metabolism, it is possible that a $p d h$ mutation affects symbiotic interaction at different stages. Here we have shown that growth on $\mathrm{C}_{4}$-dicarboxylates (succinate) as sole carbon source, under oxic or microoxic free-living conditions, results in weak $p d h$ gene expression. By contrast, we have shown by both RT-PCR and primer extension that transcription of $p d h A$ is enhanced under symbiotic conditions. Higher PDH synthesis could fulfill a so far unknown physiological need of the bacteroid, requiring an increase in acetyl-CoA synthesis. Acetyl-CoA has two major roles in the cell: (i) acetyl-CoA allows energy production upon oxidation in the TCA cycle; and (ii) acetyl-CoA is a precursor for fatty acid biosynthesis. Hence, an increase in acetyl-CoA synthesis could serve either function in bacteroids.

Alternatively, it is possible that high expression of $p d h$ is not essential for bacteroid metabolism. Engineering an $S$. meliloti mutant with a low constitutive expression of $p d h A$ in bacteroids may help answer this question.

\section{Pyruvate regulation of $p d h$ expression.}

Studies of $p d h A$ expression in $S$. meliloti cells grown on different carbon sources showed induction of $p d h A$ expression by pyruvate. No induction was observed in minimal medium containing acetate or succinate. Thus, pyruvate was a specific inducer of $p d h A$ expression in free-living conditions. Kinetics of $p d h A$ induction by pyruvate showed that induction started to be detectable 5 min after pyruvate addition. In this time frame, it is unlikely that pyruvate was metabolized, so the fast 
kinetics are in favor of pyruvate being the actual inducer molecule.

Induction by pyruvate was also observed in E. coli (Quail et al. 1994). In this case, a pyruvate-sensitive repressor, PdhR, regulates PDH gene expression (Quail and Guest 1995). PdhR represses $p d h$ transcription by binding to a palindromic operator site. Repression is antagonized in a concentrationdependent manner by pyruvate as co-effector. Thus, it is possible that a $p d h R$ homologue exists in $S$. meliloti, even though it is not immediately linked to $p d h$ genes, contrary to what exists in $E$. coli. However, no sequence similarity with the $E$. coli PdhR binding site was detected in the S. meliloti pdhA promoter. Thus, the genetic circuit that mediates pyruvate induction in $S$. meliloti needs to be elucidated.

In $S$. meliloti, $\mathrm{N}_{2}$-fixation gene expression (nif and fix regulons) is under the control of a regulatory cascade that mediates oxygen signaling via the FixLJ pair of regulatory proteins (Soupène et al. 1995). pdhA symbiotic activation does not depend on nif and fix gene cascade regulation, nor on oxygen status and nitrogen fixation, and thus differs from most of the $S$. meliloti genes studied so far. Interestingly, this indicates a new type of symbiotic regulation. pdhA transcription start site analysis showed that the same promoter was used under symbiotic conditions and in free-living cultures supplemented with pyruvate. In spite of pyruvate activation being less than symbiotic, these results suggest that regulation by pyruvate could be symbiotically relevant. Such a model would imply a high pyruvate level in bacteroids. This has not been measured to date. However, we note that a recently proposed alternative for dinitrogen transfer between the bacteroid and its plant host involves alanine (Waters et al. 1998). Alanine would be synthesized by alanine dehydrogenase, which converts pyruvate to alanine with ammonium and $\mathrm{NADH}\left(\mathrm{NADH}+\mathrm{NH}_{4}{ }^{+}+\right.$pyruvate $\rightarrow$ L-alanine $+\mathrm{NAD}^{+}+\mathrm{H}_{2} \mathrm{O}$ ). So, we speculate that a high level of pyruvate in symbiotic bacteria could be required for ammonium assimilation and export. However, it is also possible that $p d h A$ expression escapes pyruvate regulation in bacteroids. This would be the case if, for example, $p d h A$ expression was under negative control, as in E. coli, and if the pyruvate-sensing repressor was, for some reason, inactive in symbiosis. Further characterization of $p d h$ gene regulation will shed light on this question and may lead to the elucidation of the mechanisms regulating PDH genes during the symbiotic interaction with the host plant.

\section{MATERIALS AND METHODS}

\section{Microbiological techniques.}

All S. meliloti strains used in this study were isogenic with GMI 211 ( $\mathrm{lac} \mathrm{Sm}^{r}$ ) (David et al. 1988). GMI 5601 (lac nifAZ239::Tn5) and GMI 5704 (lac fixJ2.3::Tn5) were constructed by David et al. (1988). GMI 942 was constructed by Foussard et al. (1997). S. meliloti strains were grown at $30^{\circ} \mathrm{C}$ in TY complex medium (Rosenberg et al. 1981) or in defined M9 media (Miller 1972) supplemented with $0.3 \mathrm{mM} \mathrm{CaCl}_{2}, 1$ $\mathrm{mM} \mathrm{MgSO}_{4}$ and $2 \mu \mathrm{M}$ biotin. Sterilized carbon sources were added at $20 \mathrm{mM}$ final concentration. Microoxic conditions were achieved either as described by de Philip et al. (1990) ( $2 \%$ oxygen for $4 \mathrm{~h}$ ), or with the stoppered tube assay (STA) described by Ditta et al. (1987) $(<1 \%$ oxygen for $16 \mathrm{~h})$. To test induction of $p d h A$ expression by pyruvate, S. meliloti strains were grown to $\mathrm{OD}_{600}=0.3$ in $\mathrm{M} 9$ medium supplemented with $0.3 \mathrm{mM} \mathrm{CaCl}_{2}, 1 \mathrm{mM} \mathrm{MgSO}_{4}$ and $2 \mu \mathrm{M}$ biotin, and the appropriate carbon source $(20 \mathrm{mM})$. Then, pyruvate $(20 \mathrm{mM})$ was added and samples were collected after 4 or $16 \mathrm{~h}$. For the kinetics experiments (shown in Figure 6B), strains were grown to $\mathrm{OD}_{600}=0.5$ instead of $\mathrm{OD}_{600}=0.3$.

\section{DNA methods.}

Standard DNA techniques were as described previously by Sambrook et al. (1989). S. meliloti genomic DNA was prepared from free-living cells as described by Chen and Kuo (1993). For Southern blot analysis, $1 \mu \mathrm{g}$ of genomic DNA was digested for $20 \mathrm{~h}\left(37^{\circ} \mathrm{C}\right)$ with BamHI, EcoRI, HindIII, SalI, or SmaI. Restriction fragments were separated on a $0.8 \%$ agarose gel, blotted onto a nylon membrane (Biodyne A transfer membrane; Pall, East Hills, NY) and hybridized to a $p d h A$ (A1-A2) ${ }^{32} \mathrm{P}$-labeled probe. Washing was carried out in $0.1 \times$ SSC ( $1 \times \mathrm{SSC}$ is $0.15 \mathrm{M} \mathrm{NaCl}$ plus $0.015 \mathrm{M}$ sodium citrate), $0.1 \%$ SDS (sodium dodecyl sulfate) at $42^{\circ} \mathrm{C}$ for $30 \mathrm{~min}$.

A cosmid library was constructed by Tania Arcondeguy by ligation of a partial Sau3A digest of S. meliloti total DNA in the pLAFR3 cosmid vector. Screening of the library by colony hybridization was performed as recommended by Sambrook et al. (1989).

Sequence of the $p d h$ region was determined on both DNA strands by a primer-walking approach with cosmid vector DNA as template. Cosmid DNA was prepared with the Qiagen plasmid purification kit (Qiagen, Hilden, Germany), with vigorous pipetting during the lysis and neutralizing steps. Cosmid was sequenced with the ABI PRISM Dye terminator cycle-sequencing ready reaction kit (Perkin-Elmer, Oak Brook, IL), with the ABI 373 automated sequencer (ABI, Columbia, MD). Two micrograms of DNA, $4 \mu \mathrm{l}$ of Dye terminator mix, and 15 pmol of primer were mixed in a total reaction volume of $10 \mu \mathrm{l}$. This mix was denatured at $96^{\circ} \mathrm{C}$ for 5 min, followed by 90 thermal cycles $\left(96^{\circ} \mathrm{C} 30 \mathrm{~s}, 50^{\circ} \mathrm{C} 30 \mathrm{~s}\right.$, $60^{\circ} \mathrm{C} 4 \mathrm{~min}$ ). Excess Dye terminator was removed by filtration over Bio-gel P-10 (Bio-Rad Laboratories, Hercules, CA) with a MultiScreen filtration system (Millipore, Bedford, MA).

Sequence assembly was achieved with the Contig Assembly Program (Huang 1992). Data base searches were conducted through the NCBI web site with the BLAST2 package program (Altschul et al. 1997). ORFs were predicted with the GLIMMER program (Salzberg et al. 1998) and NCBIBLASTX comparisons against the NCBI-nr data base.

\section{Plant methods and preparation of endosymbiotic bacteria.}

Medicago sativa cv. Gemini seedlings were aseptically grown on agar slants made with nitrogen-free Fahraeus medium. Three-day-old plants were inoculated with the different $S$. meliloti strains. Nodules $(0.25 \mathrm{~g})$ were harvested and immediately frozen in liquid nitrogen 2 weeks after inoculation in the case of $\mathrm{Fix}^{-}$strains, and 3 weeks for $\mathrm{Fix}^{+}$strains. Nodules were ground in liquid nitrogen with a mortar and pestle, and the powder was suspended in $2 \mathrm{ml}$ of $50 \mathrm{mM}$ Tris hydrochloride (pH 7.6), $500 \mathrm{mM}$ mannitol. Debris were sedimented by centrifugation for $5 \mathrm{~min}$ at $800 \times \mathrm{g}$. Bacteroids were pelleted by centrifugation of the supernatant for $5 \mathrm{~min}$ at 12,000 $\times g$, and stored at $-80^{\circ} \mathrm{C}$ if necessary. 


\section{RNA preparation.}

The bacteria from a $25-\mathrm{ml}$ culture $\left(\mathrm{OD}_{600}=0.5\right)$ or from $0.25 \mathrm{~g}$ of nodules were resuspended and incubated for $10 \mathrm{~min}$ at $65^{\circ} \mathrm{C}$ in $2 \mathrm{ml}$ of prewarmed lysis solution (1.4\% SDS, 4 $\mathrm{mM}$ EDTA, $75 \mu \mathrm{g}$ of proteinase K). Proteins were precipitated by adding $1 \mathrm{ml}$ of $\mathrm{NaCl} 5 \mathrm{M}$ at $4^{\circ} \mathrm{C}$. Nucleic acids were precipitated from the supernatant by addition of 1 volume of isopropanol and the pellet was resuspended in nuclease-free water. DNA was eliminated by addition of $7.5 \mathrm{U}$ of FPLC-pure RNase-free DNase I (Amersham-Pharmacia Biotech, Buckinghamshire, U.K.). RNAs were further extracted with phenol/ chloroform/isoamylalcohol and chloroform/isoamylalcohol, then precipitated with ethanol. The RNA pellet was washed with 70\% ethanol and resuspended in nuclease-free water. RNAs were quantitated by measuring the absorbency at 260 $\mathrm{nm}$. Absence of contaminating DNA in the preparation was ensured by PCR amplification.

\section{RT-PCR analyses.}

The following oligonucleotides were used to evaluate gene expression:

For pdhA (see Figure 1):

A1 (sense primer) 5'-CGGAGCATGATCCG

A2 (reverse primer) $5^{\prime}$-TTGTCCCTCCCCGG

A3 (reverse primer) 5'-AGCCACTTGGAGAGCGTGC

A4 (reverse primer)

5'-TTGGCCGGCTTGGCAGCGGTCTTGCGGCTG

A5 (sense primer) 5'-TTTTCTTTCCCTATGGTAGC

A6 (sense primer) 5'-GCGAAAATCCGCGTCCG

A7 (reverse primer) 5'-ACGCCGGATCAACAGC

For hemA (accession no. P08080):

hemAr (reverse primer) 5'-GTCGATCGCGTTCTT

hemAs (sense primer) 5'-TGGATGGGCTGCATCA

First-strand cDNA synthesis took place in a $17-\mu l$ reaction volume. One microliter of total bacterial RNA (100 ng), $7.1 \mu \mathrm{l}$ of DEPC (diethyl pyrocarbonate)-treated $\mathrm{H}_{2} \mathrm{O}$, and $1 \mu \mathrm{l}(50$ ng) of the reverse primer were heated at $70^{\circ} \mathrm{C}$ for $10 \mathrm{~min}$ and quickly chilled on ice. After brief centrifugation, $3.4 \mu \mathrm{l}$ of the following $5 \times$ buffer $(250 \mathrm{mM}$ Tris- $\mathrm{HCl} \mathrm{pH} 8.3,375 \mathrm{mM} \mathrm{KCl}$, $15 \mathrm{mM} \mathrm{MgCl} 2$ ), $2 \mu \mathrm{l}$ of $0.1 \mathrm{M}$ DTT (dithiothreitol), and $1 \mu \mathrm{l}$ of a $25 \mathrm{mM}$ dNTP solution were added and incubated at $42^{\circ} \mathrm{C}$ for $2 \mathrm{~min}$. After addition of $1 \mu \mathrm{l}(200 \mathrm{U})$ of MMLV (Maloney Murine leukemia virus) reverse transcriptase and thorough mixing, the reaction tube was incubated for $50 \mathrm{~min}$ at $42^{\circ} \mathrm{C}$. Reverse transcriptase was inactivated by heating at $95^{\circ} \mathrm{C}$ for 5 min because heating at $70^{\circ} \mathrm{C}$ did not fully inactivate the enzyme.

For PCR amplification, $2.5 \mu \mathrm{l}$ of $10 \times$ PCR buffer $(200 \mathrm{mM}$ Tris- $\mathrm{HCl} \mathrm{pH} \mathrm{8.4,} 500 \mathrm{mM} \mathrm{KCl}), 1 \mu \mathrm{l}$ of $50 \mathrm{mM} \mathrm{MgCl} 2,1 \mu \mathrm{l}$ of dNTP mix $(25 \mathrm{mM}), 1 \mu \mathrm{l}$ of reverse primer $(50 \mathrm{ng}), 1 \mu \mathrm{l}$ of sense primer $(50 \mathrm{ng})$, and $0.5 \mu \mathrm{l}(2.5 \mathrm{U})$ of Taq DNA polymerase were added to the first-strand synthesis reaction mix. After gentle mixing, the reaction mixture was layered with 1 drop of silicone oil, heated to $94^{\circ} \mathrm{C}$ for $3 \mathrm{~min}$, and submitted to 25 cycles of the sequence $94^{\circ} \mathrm{C} / 30 \mathrm{~s}, 50^{\circ} \mathrm{C} / 30 \mathrm{~s}, 72^{\circ} \mathrm{C} / 1$ min, followed by 1 cycle at $72^{\circ} \mathrm{C} / 10 \mathrm{~min}$. RT-PCR products were electrophoresed on a $2 \%$ agarose gel, blotted onto a nylon membrane (Biodyne A Transfer membrane; Pall, East Hills, NY) and probed with a ${ }^{32} \mathrm{P}$-labeled DNA probe, internal to the gene of interest. Washing was carried out in $0.1 \times \mathrm{SSC}$, $0.1 \% \mathrm{SDS}$ at $42^{\circ} \mathrm{C}$ for $30 \mathrm{~min}$.

\section{Mapping of the $p d h A$ transcriptional start site.}

The transcriptional start site of $p d h A$ was mapped by primer extension as described previously (Batut et al. 1989). The purified A4 oligonucleotide was used to prime the action of the reverse transcriptase (Superscript II RT; Life Technologies, Rockville, MD). RNA-primer hybridization was performed at $45^{\circ} \mathrm{C}$ with $2.5 \mu \mathrm{g}$ of RNA, and the extension reaction was run at $50^{\circ} \mathrm{C}$. A dideoxy sequencing reaction of a DNA sample containing the $p d h A$ promoter was generated with the A4 oligonucleotide as primer, and run in parallel to the primer extension reactions.

\section{ACKNOWLEDGMENTS}

We thank T. Arcondéguy for access to her S. meliloti genomic library, L. Sauviac for automatic cycle sequencing, and J. Gouzy for help in sequence analysis. We are grateful to M. Osteras for fruitful discussions, and to N. Lindley for critical reading of the manuscript. This work was supported in part by a grant from the European Union in the frame of the BIOTECH program (FIXNET, BIOT4-CT97-2319). D. C. was supported by a doctoral fellowship from the French Ministère de l'Enseignement Supérieur et de la Recherche, and by the FIXNET program.

\section{LITERATURE CITED}

Altschul, S. F., Madden, T. L., Schaffer, A. A., Zhang, J., Zhang, Z., Miller, W., and Lipman, D. J. 1997. Gapped BLAST and PSI-BLAST: A new generation of protein database search programs. Nucleic Acids Res. 25:3389-3402.

Andersson, S. G., Zomorodipour, A., Andersson, J. O., Sicheritz-Ponten, T., Alsmark, U. C., Podowski, R. M., Naslund, A. K., Eriksson, A. S., Winkler, H. H., and Kurland, C. G. 1998. The genome sequence of Rickettsia prowazekii and the origin of mitochondria. Nature 396:133140.

Batut, J., Daveran-Mingot, M. L., David, M., Jacobs, J., Garnerone, A. M., and Kahn, D. 1989. fixK, a gene homologous with fnr and $c r p$ from Escherichia coli, regulates nitrogen fixation genes both positively and negatively in Rhizobium meliloti. EMBO J. 8:1279-1286.

Berg, A., and de Kok, A. 1997. 2-Oxo acid dehydrogenase multienzyme complexes. The central role of the lipoyl domain. Biol. Chem. 378: 617-634.

Chen, W. P., and Kuo, T. T. 1993. A simple and rapid method for the preparation of Gram-negative bacterial genomic DNA. Nucleic Acids Res. 21:2260-2260.

David, M., Daveran, M. L., Batut, J., Dedieu, A., Domergue, O., Ghai, J., Hertig, C., Boistard, P., and Kahn, D. 1988. Cascade regulation of nif gene expression in Rhizobium meliloti. Cell 54:671-683.

de Kok, A., Hengeveld, A. F., Martin, A., and Westphal, A. H. 1998. The pyruvate dehydrogenase multi-enzyme complex from Gramnegative bacteria. Biochim. Biophys. Acta 1385:353-366.

de Philip, P., Batut, J., and Boistard, P. 1990. Rhizobium meliloti FixL is an oxygen sensor and regulates $R$. meliloti nifA and fixK genes differently in Escherichia coli. J. Bacteriol. 172:4255-4262.

Ditta, G., Virts, E., Palomares, A., and Kim, C. H. 1987. The nifA gene of Rhizobium meliloti is oxygen regulated. J. Bacteriol. 169:32173223.

Driscoll, B. T., and Finan, T. M. 1993. NAD(+)-dependent malic enzyme of Rhizobium meliloti is required for symbiotic nitrogen fixation. Mol. Microbiol. 7:865-873.

Driscoll, B. T., and Finan, T. M. 1997. Properties of NAD(+)- and NADP(+)-dependent malic enzymes of Rhizobium (Sinorhizobium) meliloti and differential expression of their genes in nitrogen-fixing bacteroids. Microbiology 143(pt 2):489-498.

Engelke, T. H., Jagadish, M. N., and Puhler, A. 1987. Biochemical and genetical analysis of Rhizobium meliloti mutants defective in $\mathrm{C}_{4}{ }^{-}$ dicarboxylate transport. J. Gen. Microbiol. 133:3019-3029.

Finan, T. M., McWhinnie, E., Driscoll, B., and Watson, R. J. 1991. Complex symbiotic phenotypes result from gluconeogenic mutations in Rhizobium meliloti. Mol. Plant-Microbe Interact. 4:386-392.

Fischer, H. M. 1994. Genetic regulation of nitrogen fixation in Rhizobia. 
Microbiol. Rev. 58:352-386.

Foussard, M., Garnerone, A. M., Ni, F., Soupène, E., Boistard, P., and Batut, J. 1997. Negative autoregulation of the Rhizobium meliloti fixK gene is indirect and requires a newly identified regulator, FixT. Mol. Microbiol. 25:27-37.

Hawkins, C. F., Borges, A., and Perham, R. N. 1989. A common structural motif in thiamin pyrophosphate-binding enzymes. FEBS Lett. 255:77-82.

Hein, S., and Steinbuchel, A. 1996. Cloning and characterization of the Alcaligenes eutrophus 2-oxoglutarate dehydrogenase complex. FEMS Microbiol. Lett. 136:231-238.

Hengeveld, A. F., Westphal, A. H., and de Kok, A. 1997. Expression and characterisation of the homodimeric E1 component of the Azotobacter vinelandii pyruvate dehydrogenase complex. Eur. J. Biochem. 250: 260-268.

Huang, X. 1992. A contig assembly program based on sensitive detection of fragment overlaps. Genomics 14:18-25.

McRae, D. G., Miller, R. W., Berndt, W. B., and Joy, K. 1989. Transport of $\mathrm{C}_{4}$-dicarboxylates and amino acids by Rhizobium meliloti bacteroids. Mol. Plant-Microbe Interact. 2:273-278.

Miller, J. H. 1972. Experiments in Molecular Genetics. Cold Spring Harbor Laboratory, Cold Spring Harbor, NY.

Miller, R. W., McRae, D. G., and Joy, K. 1991. Glutamate and $\gamma$-aminobutyrate metabolism in isolated Rhizobium meliloti bacteroids. Mol. Plant-Microbe Interact. 4:37-45.

Mylona, P., Pawlowski, K., and Bisseling, T. 1995. Symbiotic nitrogen fixation. Plant Cell 7:869-885.

Neveling, U., Bringer-Meyer, S., and Sahm, H. 1998a. Gene and subunit organization of bacterial pyruvate dehydrogenase complexes. Biochim. Biophys. Acta 1385:367-372.

Neveling, U., Klasen, R., Bringer-Meyer, S., and Sahm, H. 1998b. Purification of the pyruvate dehydrogenase multienzyme complex of $Z y$ momonas mobilis and identification and sequence analysis of the corresponding genes. J. Bacteriol. 180:1540-1548.

Patel, M. S., and Roche, T. E. 1990. Molecular biology and biochemistry of pyruvate dehydrogenase complexes. FASEB J. 4:3224-3233.

Powles, R., and Rawlings, D. 1997. The pyruvate dehydrogenase complex of the chemolithoautotrophic bacterium Thiobacillus ferrooxidans has an unusual E2-E3 subunit fusion. Microbiology 143(pt 7): 2189-2195.

Preisig, O., Anthamatten, D., and Hennecke, H. 1993. Genes for a microaerobically induced oxidase complex in Bradyrhizobium japoni- cum are essential for a nitrogen-fixing endosymbiosis. Proc. Natl. Acad. Sci. USA 90:3309-3313.

Quail, M. A., and Guest, J. R. 1995. Purification, characterization and mode of action of PdhR, the transcriptional repressor of the $p d h R$ aceEF-lpd operon of Escherichia coli. Mol. Microbiol. 15:519-529.

Quail, M. A., Haydon, D. J., and Guest, J. R. 1994. The pdhR-aceEF-lpd operon of Escherichia coli expresses the pyruvate dehydrogenase complex. Mol. Microbiol. 12:95-104.

Rae, J. L., Cutfield, J. F., and Lamont, I. L. 1997. Sequences and expression of pyruvate dehydrogenase genes from Pseudomonas aeruginosa. J. Bacteriol. 179:3561-3571

Ronson, C. W., Lyttleton, P., and Robertson, J. G. 1981. C 4 -dicarboxylate transport mutants of Rhizobium trifolii form ineffective nodules on Trifolii repens. Proc. Natl. Acad. Sci. USA 78:4284-4288.

Rosenberg, C., Boistard, P., Denarie, J., and Casse-Delbart, F. 1981. Genes controlling early and late functions in symbiosis are located on a megaplasmid in Rhizobium meliloti. Mol. Gen. Genet. 184:326-333.

Russell, G. C., and Guest, J. R. 1991. Sequence similarities within the family of dihydrolipoamide acyltransferases and discovery of a previously unidentified fungal enzyme. Biochim. Biophys. Acta 1076:225232.

Salzberg, S. L., Delcher, A. L., Kasif, S., and White, O. 1998. Microbial gene identification using interpolated Markov models. Nucleic Acids Res. 26:544-548.

Sambrook, J., Fritsch, E. F., and Maniatis, T. A. 1989. Molecular Cloning: A Laboratory Manual. 2nd ed. Cold Spring Harbor Laboratory, Cold Spring Harbor, NY.

Soupène, E., Foussard, M., Boistard, P., Truchet, G., and Batut, J. 1995. Oxygen as a key developmental regulator of Rhizobium meliloti $\mathrm{N}_{2^{-}}$ fixation gene expression within the alfalfa root nodule. Proc. Natl. Acad. Sci. USA 92:3759-3763.

Waters, J. K., Hughes, B. L., Purcell, L. C., Gerhardt, K. O., Mawhinney, T. P., and Emerich, D. W. 1998. Alanine, not ammonia, is excreted from $\mathrm{N}_{2}$-fixing soybean nodule bacteroids. Proc. Natl. Acad. Sci. USA 95:12038-12042.

Welsh, J., Chada, K., Dalal, S. S., Cheng, R., Ralph, D., and McClelland, M. 1992. Arbitrarily primed PCR fingerprinting of RNA. Nucleic Acids Res. 20:4965-4970.

Wong, K. K., and McClelland, M. 1994. Stress-inducible gene of Salmonella typhimurium identified by arbitrarily primed PCR of RNA. Proc. Natl. Acad. Sci. USA 91:639-643. 